Material e Métodos: trata-se de um estudo transversal e retrospectivo no qual foram incluídos 843 fetos provenientes da clinica Gennus de Belo Horizonte, com idade gestacional entre 10 e 14 semanas confirmada através do comprimento cabeça-nádegas $(\mathrm{CCN})$ entre 38-84 mm. Foram incluídos recém-nascidos a termo, vivos, fenotipicamentes normais. A localização dopplerfluxométrica do ducto venoso foi feita através de corte longitudinal, para-sagital direito no nível do tronco, onde observa-se a sua união à veia cava inferior através de seu padrão característico de alta velocidade de fluxo, fato que levou à sua representação com expressiva intensidade de cor. A janela do Doppler pulsátil foi colocada na porção média do ducto, entre o ducto proximal (seio umbilical) e a porção distal (união do ducto venoso e veia cava inferior). Curvas de referência foram construídas para todos os parâmetros estudados. Resultados: a velocidade do fluxo sangüíneo no ducto venoso aumentou na sístole ventricular (onda S), na diastole ventricular (onda D), na contração atrial (onda
A) e na Tmax, com o avançar da idade gestacional. Em relação ao comportamento do IPVV e do IPV, não se observou alteração com o evoluir da gestação, tendo o IPV mostrado uma tendência (sem significância estatística) a aumento gradual até o CCN de $63 \mathrm{~mm}$ (12 semanas e seis dias), quando ocorreu queda progressiva. Conclusão: $O$ estudo da velocidade do fluxo sangüineo no ducto venoso demostrou aumento progressivo nas diferentes fases da onda, secundário a alterações hemodinâmicas, tanto na pré-carga como na pós-carga, entre a $10^{\mathrm{a}}$ e a $14^{\mathrm{a}}$ semanas de gestação. Em relação ao estudo dos índices estudados, o IPV apresentou tendência a aumento gradual até o CCN de $63 \mathrm{~mm}$, quando ocorreu queda progressiva. O IPVV não apresentou correlação com o aumento do CCN entre 10 e 14 semanas de gestação.

PALAVRAS-CHAVE: Ducto venoso; Gravidez normal; Dopplervelocimetria

Resumos de Tese

\title{
Efeito imuno-histoquimico, molecular e morfológico das isoflavonas no útero de ratas
}

\section{The imunohistochemistry molecular and morphological effectcs of isoflavones on the rat uterus}

Autora: Rejane Mosquette

Orientadores: Prof.Dr. Manuel de Jesus Simões

Prof.Dr. José Maria Soares Junior

Tese apresentada à Universidade Federal de São Paulo - Escola Paulista de Medicina, para obtenção do título de Mestre, em 24 de novembro de 2004

Objetivos: avaliar os efeitos das isoflavonas no útero de ratas castradas, comparando-os aos dos estrogênios por técnicas histológicas, morfológicas, imunohistoquímicas e de biologia molecular. Métodos: ratas adultas após 28 dias de castração foram divididas ao acaso em sete grupos iguais: Gp animais que receberam propilenoglicol; G10, G50, G100, G300 e G600 animais que receberam respectivamente $10,50,100,300$ e $600 \mathrm{mg} / \mathrm{kg}$ de extrato de soja $^{1}$ enriquecido com isoflavonas e GE animais tratados com estrogênios conjugados eqüinos $(200 \mathrm{mg} / \mathrm{kg})$. Todos os animais receberam por 21 dias consecutivos por gavagem os produtos, sendo sacrificados sob anestesia ao final. Fragmentos dos úteros foram mergulhados em formol a $10 \%$ para estudo histológico e imuno-histoquimico (fator de crescimento vascular endotelial - VEGF, e de proliferação nuclear - PCNA). Outros foram rapidamente mergulhados em nitrogênio líquido para extração do RNA e avaliação do gene do VEGF pela técnica da transcriptase reversa (RT-PCR). Resultados: notamos que doses de estrato de soja igual ou superior a 300 $\mathrm{mg} / \mathrm{kg}$ estimulam a espessura do endométrio $(\mathrm{Gp}=$ $12,7 \pm 0,3 \mathrm{~mm}$; G300 = 75,7 $\pm 1,2 \mathrm{~mm}$ ). Os mesmos dados foram observados em relação a imuno-histoquimica para o PCNA (número de mitoses em 1000 células Epitélio luminal Gp $=4,2 \pm 2,8 ; \mathrm{G} 300=74,9 \pm 13,7$; epitélio glandular $\mathrm{Gp}=7,1 \pm 6,6 ; \mathrm{G} 300=95,7 \pm 4,9$; lâmina própria $\mathrm{Gp}=0,2 \pm 0,3 ; \mathrm{G} 300=20,4 \pm 1,8$ ) e para o VEGF (intensa positividade). No entanto para o RTPCR do VEGF doses iguais ou superiores a $50 \mathrm{mg} / \mathrm{kg}$ já mostraram a presença de nítidas bandas indicando ação trófica das isoflavonas. Os estrogênios apresentaram efeitos tróficos em todos os parâmetros estudados. Conclusões: as isoflavonas apresentam ação trófica sobre o útero de ratas castradas dependendo da dose administrada.

PALAVRAS-CHAVE: Isoflavonas; Endométrio; VEGF; Ciclo celular

\footnotetext{
${ }^{1}$ Extrato de soja cedido pela SP Farma, contendo 425,5 $\mathrm{mg}$ de isoflavonas por grama de extrato.
} 